\title{
Lagarobasidium calongei (Aphyllophorales, Basidiomycota), a new species of corticioid fungi from Azores Islands
}

\author{
by

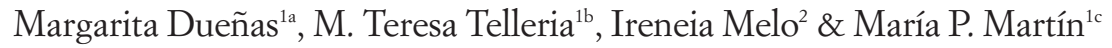 \\ ${ }^{1}$ Real Jardín Botánico, CSIC, Plaza de Murillo 2, E-28014 Madrid, Spain \\ mduenas@rjb.csic.es ${ }^{1 a}$, telleria@rib.csic.es ${ }^{1 \mathrm{~b}}$, maripaz@ $@$ rib.csic.es ${ }^{1 \mathrm{c}}$ \\ ${ }^{2}$ Jardim Botânico (MNHN), Universidade de Lisboa/CBA-FCUL, Rua da Escola Politécnica 58, \\ 1250-102 Lisboa, Portugal \\ mimelo@fc.ul.pt
}

\begin{abstract}
Dueñas, M. Telleria, M.T., Melo, I. \& Martín, M.P. 2009. Lagarobasidium calongei (Aphyllophorales, Basidiomycota), a new species of corticioid fungi from Azores Islands. Anales Jard. Bot. Madrid 66S1: 41-46.

On the base of morphologic and molecular studies, a new species of the genus Lagarobasidium (Aphyllophorales, Basidiomycota), is described and illustrated. This new species was collected on Pico Island (Azores) and is characterized by having two types of cystidia, clavate leptocystidia and cylindrical skeletocystidia, and smooth, thick-walled spores. It is compared with Lagarobasidium detriticum (Bourdot) Jülich and L. cymosum (D.P. Rogers \& H.S. Jacks.) Jülich, until now the only two species of the genus.
\end{abstract}

Keywords: Corticiaceae, mycobiota, taxonomy, Atlantic Islands, Macaronesia.

\section{Introduction}

The genus Lagarobasidium was described by Jülich (1974) to include corticioid species with "basidiocarp effused, hymenial surface even or odontoid, hyphal system monomitic, cystidia or cystidiols present, basidia smaller than $20 \mu \mathrm{m}$ and spores smooth, ellipsoidal, thick-walled, often guttulate, not amyloid". He included three species in the genus: Lagarobasidium pruinosum (Bres.) Jülich and L. nikolajevae (Parmasto) Jülich, considered synonymous of Hypochnicium detriticum (Bourdot) J. Erikss. \& Ryvarden by Eriksson \& Ryvarden (1976) and L. cymosum (D.P. Rogers \& H.S. Jacks.) Jülich.

\section{Resumen}

Dueñas, M. Telleria, M.T., Melo, I. \& Martín, M.P. 2009. Lagarobasidium calongei (Aphyllophorales, Basidiomycota), una nueva especie de las Islas Azores. Anales Jard. Bot. Madrid 66S1 : 41-46 (en inglés).

Sobre la base de estudios morfológicos y moleculares se describe e ilustra una nueva especie dentro del género Lagarobasidium (Aphyllophorales, Basidiomycota). Esta nueva especie, recolectada en la isla de Pico (Azores), se caracteriza por presentar dos tipos de cistidios, leptocistidios claviformes y esqueletocistidios cilíndricos, y esporas lisas con paredes gruesas. Se compara con Lagarobasidium detriticum (Bourdot) Jülich y L. cymosum (D.P. Rogers \& H.S. Jacks.) Jülich, las otras dos especies del género.

Palabras clave: corticiáceos, micobiota, islas atlánticas, Macaronesia.

Later, Jülich (1979) transferred H. detriticum to the genus Lagarobasidium, L. detriticum (Bourdot) Jülich, due to its striking microscopic characteristics, clavate cystidia and thick-walled cyanophilous spores. The species described here was collected from one locality in Pico Island (Azores archipelago) and shows close affinity to $L$. detriticum, although differing in that it has two types of cystidia.

There are different opinions about the taxonomic position of L. detriticum -Langer (1994), for instance, included it in Hyphodontia- but the molecular analysis of samples deposited in MA herbarium shows that it belongs to a genus different from Hyphodontia and Hypochnicium. 


\section{Materials and methods}

The sample under study was collected on Pico Island, during a mycological foray to the islands from the central group of Azores archipelago at the end of the winter of 2005, on a Laurus azorica (Seub.) Franco remnant plot, accompanied by Erica azorica Hochst. ex Seub., Myrica faya Aiton, Picconia azorica (Tutin) Knobl., Pittosporum undulatum Vent, Dryopteris crispifolia H. Rasbach \& al., Dryopteris affinis (Lowe) Fraser-Jenkins, Hedera azorica Hort. and Rubia agostinhoi Dansereau \& P. Silva. The material was deposited in the herbarium MA under MA-Fungi 73256. The initials Tell. correspond to M.T. Telleria.

Collections of Lagarobasidium detriticum located at the MA herbarium (MA-Fungi 5758, MA-Fungi 61397 and MA-Fungi 61402) were included for comparison.

All material was studied following classical methods for the corticioid fungi: thin, freehand sections from the specimen were mounted in $\mathrm{KOH}(5 \%)$ and/or Melzer's reagent. These sections were examined under an Olympus BH50 microscope. Line drawings and microphotographs were made with a Leyca DM 2500 microscope with camera lucida, by M. Dueñas.

Genomic DNA was extracted from the four collections using less that $10 \mathrm{mg}$ of basidiomes with E.Z.N.A.-Fungi DNA miniprep kit (Omega Biotek, Doraville, USA). DNA fragments containing internal transcribed spacers ITS1 and ITS2 including 5.8S nrDNA, were amplified with primer pair ITS1/ITS4 (White \& al., 1990) primers as described in Martín \& al. (2004). Prior to sequencing, the amplification products were cleaned using QIAquick Gel PCR purification kit (QIAGEN, Valencia, California, USA). Both strands were sequenced separately using primers ITS1 and ITS4 with AmpliTaq DNA Polymerase (Applied Biosystem) at Secugen Company (Madrid, Spain).

Sequencher (Gene Codes Corporation, Ann Arbor, Michigan, USA) was used to identify the consensus sequence from the two strands of the ITS nrDNA of each isolate. Basic Local Alignment Search Tool (BLAST) with option Standard nucleotide BLAST of BLASTN 2.2.18 were used to compare the sequence obtained against the sequences in the National Center of Biotechnology Information (NCBI) nucleotide databases (Altschul \& al., 1997). The new consensus sequences have been deposited in the EMLB database. SEQAPP software for multiple sequences was used to compare the sequences obtained in this study.

Based on morphological and molecular data a new species is proposed:

\section{Taxonomic treatment}

Lagarobasidium calongei M. Dueñas, Telleria, Melo \& M.P. Martín, sp. nov. (Figs. 1, 2, 3)

MycoBank N. ${ }^{\circ}$ : MB 51283.

Etymology: Dedicated to F.D. Calonge.

Fructificatio resupinata, tenuis, colliculosa, ab alba ad albam-luteam, margo macrescens.

Systema bypharum monomiticum, byphae fibulatae, tenuiter tunicatae; skeletocystidia cylindrica 140-160 × $5-9 \mathrm{~mm}$, leptocystidia a subclaviformis ad spatbuliformia 57-90 × 6-7 mm; basidia a subcylindrica ad urniformia 17-28 × 4-6 mm; sporae a laxe ellipticis ad subglobosas 7-8 $\times 5-6 \mathrm{~mm}$, cum parietibus crassis et levibus, non amyloideae et cyanophylae. Haec species differt ab alteris eiusdem generis per duos typos cystidiorum et per dimensionem sporarum.

Holotypus: PORTUGAL. Azores: Pico, S. Roque, Meia Encosta de Sta. Luzia, Travessa de Cima, 26SLH8064, 26-II-2005, $483 \mathrm{~m}$, on decayed wood, 16187Tell. (MA-Fungi 73256).

Basidiome resupinate, effused, hypochnoid, very thin at first, white to white-yellowish; hymenophore when young smooth, with age colliculose to grandinioid; margin not especially differentiated.

Hyphal system monomitic; hyphae distinct, thinwalled, fibulate, basal hyphae 2.5-3 $\mu$ m wide, richly branched, forming a thin subiculum that gives rise to subhymenial hyphae arranged perpendicularly, 3-4 $\mu \mathrm{m}$ wide, densely united in the more developed zone. Cystidia of two kinds, skeletocystidia that rise from the subiculum, projecting through the hymenium, cylindrical, with very thick walls except in the apical part, cyanophilous, with secondary septa without clamps, $140-160 \times(5) 7-9 \mu \mathrm{m}$ and leptocystidia originated from the subhymenial hyphae, subclaviform to spathuliform, thin-walled, 57-90 × 6-7 $\mu \mathrm{m}$ (width on the apical part); frequently capitate cystidiols. Basidia subcylindrical to urniform with constrictions, 17-28 $\times$ 4-6 $\mu \mathrm{m}$, with 4 sterigmata. Basidiospores broadly ellipsoid to subglobose, smooth, thick-walled, cyanophilous, non-amyloid, 7-8 × 5-6 $\mu \mathrm{m}$, with one oil drop and a small apiculus.

Molecular analysis: ITS nrDNA sequences were obtained from a single $L$. detriticum collection (MAFungi 5758) and L. calongei (MA-Fungi 73256). The new sequences have been logged in the EMBL database with the Accession Numbers FM876211 and FM876212, respectively. The alignment between these sequences is shown in Fig. 3. The ITS1 region has at least 68 different bases, of which 42 are due to insertions, 11 to transitions (indicated with!, 


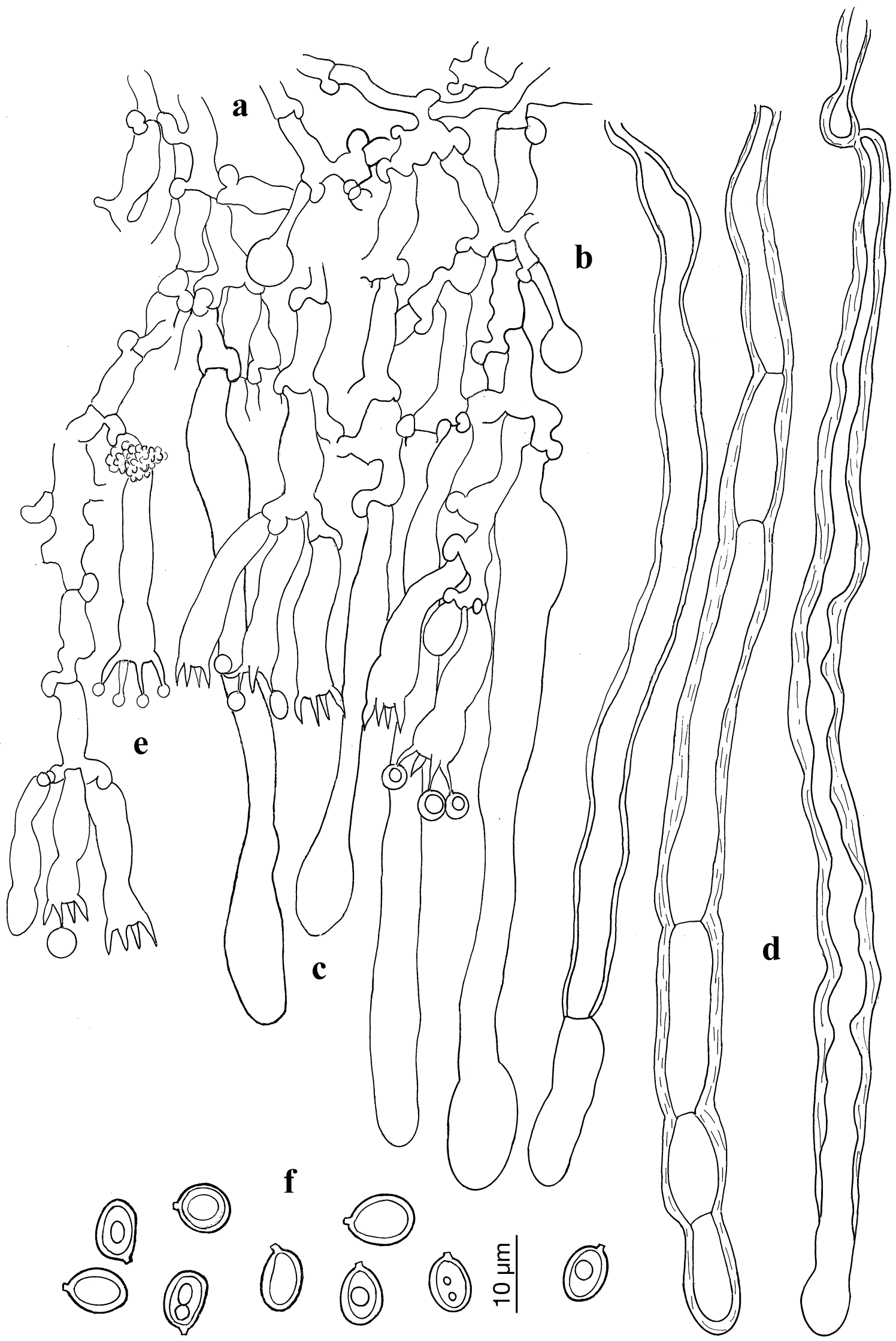

Fig. 1. Lagarobasidium calongei (MA-Fungi 73256): a, hyphae; b, capitate cystidiol; c, leptocystidia; d, skeletocystidia; e, basidia; f, spores. 

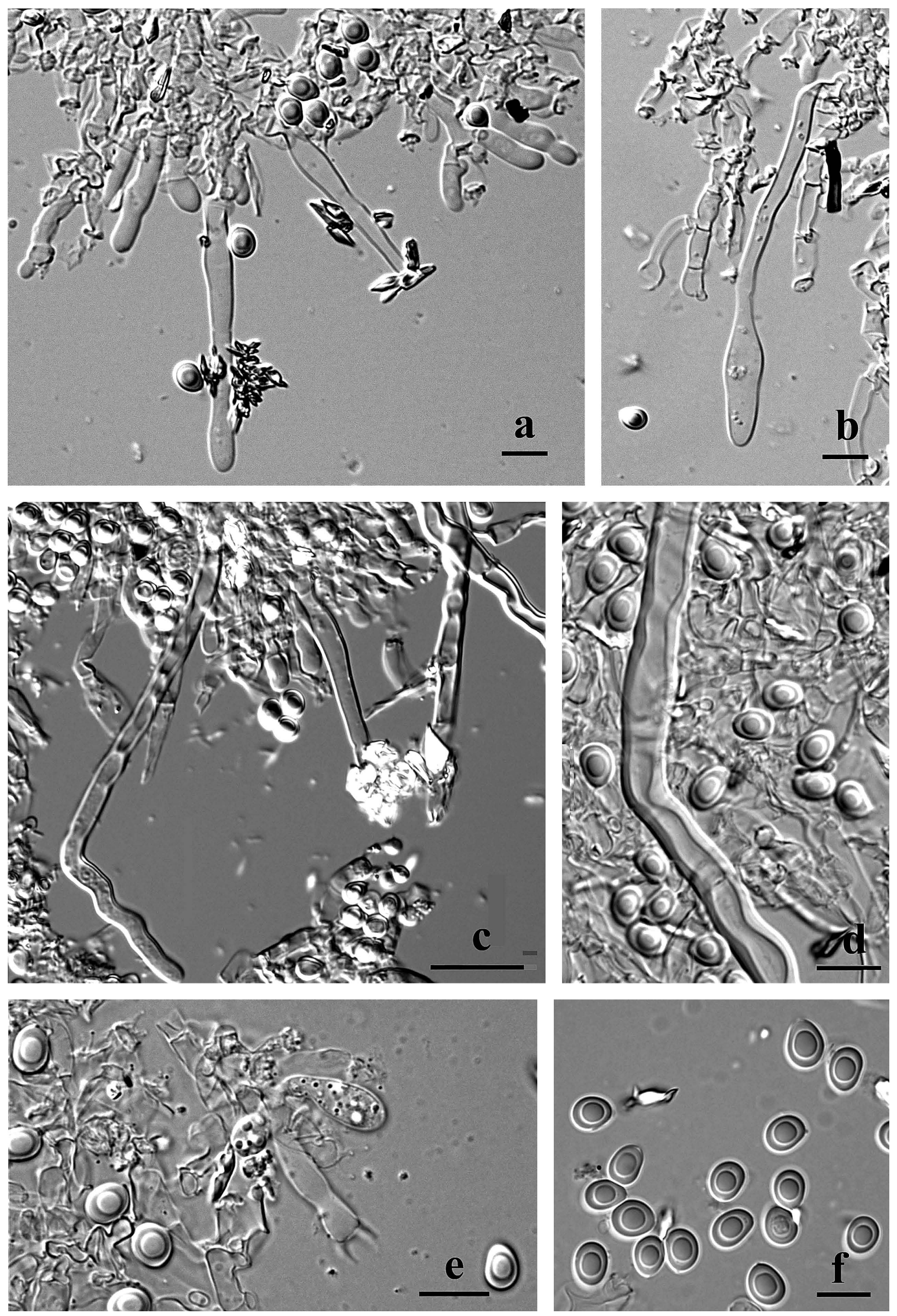

Fig. 2. Lagarobasidium calongei (MA-Fungi 73256): $\mathbf{a}$, detail of hymenium with leptocystidia (bar = $10 \mu \mathrm{m}) ; \mathbf{b}$, leptocystidia (bar $=10 \mu \mathrm{m})$; c, skeletocystidia (bar $=40 \mu \mathrm{m})$; d, spores and skeletocystidia $($ bar $=10 \mu \mathrm{m})$; e, basidia and spores $($ bar $=10 \mu \mathrm{m}) ; \mathbf{f}$, spores $($ bar $=10 \mu \mathrm{m})$. 
Fig. 3) and 12 to transversions (indicated with ?, Fig. 3). In the ITS2 region 124 bases are different, of which 86 are due to insertions, 17 to transitions and 19 to transversions.

The BLAST search did not give significant results. Neither was the sequence DQ677507 (part 5.8S nrDNA, complete ITS2 and part LSU nrDNA), located at the EMBL database under Hypochnicium detriticum, related to the sequences obtained in this study. This sequence was included in two papers (Larsson, 2007a, b) where the phylogenetic analyses show that it was closely related to Hyphodontia quercina, not to Hypochnicium species as expected from morphological characters.

\section{Discussion}

The inclusion of this species in Lagarobasidium is justified by its monomitic hyphal structure, presence of characteristic cystidia and ellipsoid, thickwalled, guttulate, non-amyloid spores. It is very close to $L$. detriticum, though it differs in having two types of cystidia, leptocystidia and skeletocystidia, and larger spores; the former species has spores 4.5-5.5(6) $\times$ 4-4.5 $\mu \mathrm{m}$. The other species in the genus, L. cymosum, is separated from the new species by its subulate cystidia and subglobose spores. Skeletocystidia have also been described in some species of Hypochnicium, such as $H$. bicystidiatum Boidin \& Gilles

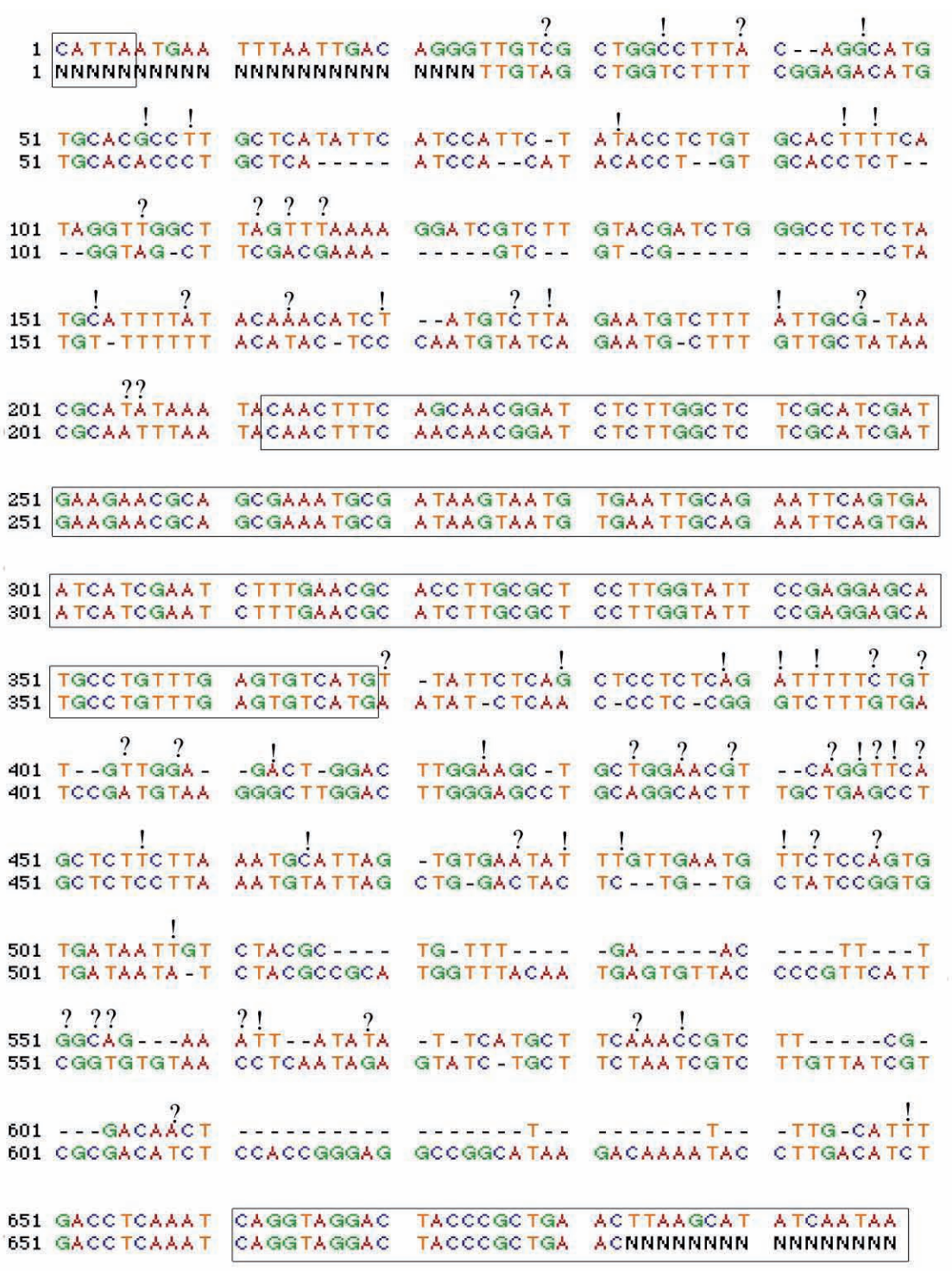

Fig. 3. Alignment of the ITS nrDNA sequences obtained for Lagarobasidium detriticum (upper row, FM876211) and L. calongei sp. nov. (lower row, FM876212). In the boxes, final part of the 18S, complete 5.8S and initial part of 28S nrDNA genes. Position 6-212: Region ITS1; Position 370-650: Region ITS2. Transitions are marked with ! and transversions with? 
(Boidin \& Gilles 2000), but the molecular analyses demonstrate that Lagarobasidium calongei is close to $L$. detriticum, not a species of the genus Hypochnicium.

\section{KEY TO LAGAROBASIDIUM SPECIES}

1. Cystidia subulate

L. cymosum

1. Cystidia otherwise (n)

2. All cystida of the same type, leptocystidia apically widened, spores 4.5-5.5 (6) × 4-4.5 $\mu$ m ellipsoid

L. detriticum

2. Two types of cystidia: leptocystidia apically widened and skeletocystidia long, tubular, thick-walled; spores 7-8 × 5-6 $\mu \mathrm{m}$, broadly ellipsoid to subglobose

L. calongei

\section{Acknowledgements}

Financial support was given by DGI project n. ${ }^{\circ}$ CGL200501192, Biogeographic interconnections of the Corticiaceae (Aphyllophorales, Basidiomycota) of the Macaronesian Islands. We thank Secretaria Regional do Ambiente and Secretaria Regional de Agricultura e Florestas of Azores for authorizing us to collect fungi in the archipelago; the curators of BPI herbaria for the loan of Lagarobasidium detriticum and L. cymosum; Jesús Muñoz Riego for his help in preparing the Latin diagnosis; our colleagues Esperanza Beltrán, Jesús Laura Rodríguez Armas and José Cardoso for all the help given in the field work; and Maria José Bettencourt, Carlos A. Pereira and Hélio J. Goulart, for their local expertise in the field, making our stay in Pico very pleasant and fruitful.

\section{References}

Altschul, S.F., Madden, T.L., Schäffer, A.A., Zhang, J., Zhang, Z., Miller, W. \& Lipman, D.J. 1997. Gapped BLAST and PSIBLAST: a new generation of protein database search programs. Nucleic Acid Research 25: 3389-3402.

Boidin, J. \& Gilles, G. 2000. Basidiomycètes Aphyllophorales de l'Île de la Réunion XX - le genre Hypochnicium Eriksson. Bulletin de la Societé Mycologique de France 116(2): 159-172.

Eriksson, J. \& Ryvarden, L. 1976. The Corticiaceae of North Europe. Vol. 4: 549-886. Fungiflora, Oslo.

Jülich, W. 1974. The genera of the Hyphodermoideae (Corticiaceae). Persoonia 8(1): 59-97.

Jülich, W. 1979. Studies in resupinate basidiomycetes VI. On some new taxa. Persoonia 10(3): 325-336.

Langer, E. 1994. The genus Hyphodontia John Eriksson. Bibliotheca Mycologica 154: 1-298

Larsson, K.-H. 2007a. Molecular phylogeny of Hyphoderma and the reinstatement of Peniophorella. Mycological Research 111: 186-195.

Larsson, K.-H. 2007b. Re-thinking the classification of corticoid fungi. Mycological Research 111: 1040-1063.

Martín, M.P., Raidl, S. \& Telleria, M.T. 2004. Molecular analyses confirm the relationship between Stephanospora caroticolor and Lidtneria trachyspora. Mycotaxon 90: 133-140.

White, T.J., Bruns, T., Lee, S. \& Taylor, J.W. 1990. Amplification and direct sequencing of fungal ribosomal RNA genes for phylogenetics. In: Innis, M.A., Gelfand, D.H., Sninsky, J.J. \& White, T.J. (eds.), PCR Protocols. A guide to methods and applications: 315-322. Academic Press Inc., San Diego, CA.

Received: 12-II-2009 Accepted: 7-IV-2009 